\title{
Comprehensive study on execution of three tyn wheel hoe at farmers field
}

Suneetha Runjala, V. Nagarjuna and E. Ravigoud

Received : 13.07.2019; Revised : 28.08.2019; Accepted : 15.09.2019

See end of the Paper for authors' affiliation

Correspondence to :

Suneetha Runjala

Krishi Vigyan Kendra

(Dr.Y.S.R.H.U.), Vonipenta

(A.P.) India

Email:srunjala@yahoo.com
ABSTRACT : In agriculture weeding has been established as one of the major drudgery prone occupation of unorganized sector due to lack of awareness and access to improved agricultural technologies. The women traditionally carried out weeding operation by using tools e.g. hand hoes in bending position which decreases the work efficiency. In order to overcome this problem, KVK, Vonipenta has organized front line demonstration entitled with work and field efficacy performance of wheel hoe in weeding activity. With this objective to reduce the drudgery with muscular stress and fatigue and work efficiency of the farmers. The demonstration component included use of weeding implement (Three tyn wheel hoe) developed by CRIDA, skill training and exposing advantages. In the recommended weeding practice, shown that the same amount of work could be done in almost half of the time and work efficiency was increased. Farmers were adopted the improved technique as it had increased the efficiency of work, reduced the drudgery and helped in avoiding bending posture. The weeding efficiency of the three tyn wheel hoe weeder was easy to operate and weeder could work upto $60 \mathrm{~mm}$ depth with field capacity of $0.048 \mathrm{ha} / \mathrm{hr}$ and higher weeding efficiency was obtained upto 96.8 per cent. During weeding operation, the peak heart rate of the subjects was found to range from 142 to 150 beats per min. In case of heavy work and dense grass infested field, the rest pause of 15 minutes was required by the subjects to come to the normal heart rate. The overall performance of the three tyn wheel hoe weeder was satisfactory.

- KEY WORDS : Drudgery index, Weeding efficiency, Economic efficiency

- HOW TO CITE THIS PAPER : Runjala, Suneetha, Nagarjuna, V. and Ravigoud, E. (2019). Comprehensive study on execution of three tyn wheel hoe at farmers field. Internat. J. Agric. Engg., 12(2) : 251-255, DOI: 10.15740/HAS/IJAE/12.2/251-255. Copyright@ 2019: Hind AgriHorticultural Society. 